高分子文集 (Kobunshi Ronbunshu), Vol. 42, No. 1, pp. 49-53 (Jan., 1985)

\title{
ポリエーテル生成反応におけるスチレンービニルペンジルトリアル キルアンモニウムクロリド共百合体の触媒奻果*
}

\author{
今井 淑夫*1 - 山绮 昇*1
}

(受付 1984 年 7 月 9 日・恋查終了 1984 年 8 月 31 日)

\begin{abstract}
昰 スチレンとクロルメチルスチレンとの共重合体を各穗トリナルキルナミンと反応させ，ス チレンービニルベンジルトリフルキルフンモニウムクロリド共重合体（I）を合成し，Iを䖵媒とし て， $\alpha, \alpha^{\prime}$-ジクロロ-p-キシレンとビスフェノール A との重樎合反忘を相間移動重合条件下で行った. スチレンービニルベンジルトリェチルアンモニウムクロリド共重合体を用いた場合, 生成ポリマーの 対数粘度は $0.74 \mathrm{~d} l \cdot \mathrm{g}^{-1}$ に達した。 またIの蚛媒効果について，ポリスチレン及びベンジルトリエチ ルアンモニウムクロリドの場合と比较検时した。
\end{abstract}

\section{1 槽}

p-キシレンジクロリト (DCPX) とビスフェノール A(BPA) とから相間移動蠂存在下でボリェーテルが合 成できることはよく知られている と BPA とからのポリエーテルの合成について諸条件を 検討し，有機相として DMSO を添加した混合溶媒系， 例えば THF-DMSO (3:1) を用いると高粘度のボリェー テルが得られることを報告しだ、゙. しかし第四フンモ ニウム塩の触媒活性は, ベンゼンのような非極性溶媒中 の方が高いが，生成ポリマーの粘度を高めるには極性溶 媒の方が有奻であるなど, 高分子量のポリェーテルを短 時間で合成しようとすると相矛盾する条件の妥協を計ら なけれぱならなかったそそこで著者らは，第四アンモ二 ウム塩の近傍をべンゼン棵で爱い，非極性穷囲気場を作 り出した場合に，効果的に高粘度のポリエーテルが合成 できるのではないかと考光本実絤を行った.すなわち， 本研究では, スチレンービニルペンジルトリアルキルア ンモニウムクロリド共重合体（分子量約 20,000）を触媒 として用いた結果, 高粘度のボリェーテルがごく短時間 で合成できたので報告する.

\section{2 实暗}

\section{1 調落}

DCPX 及び BPA は，市股品を再結晶して用いた。 ペンジルトリェチルアンモニゥムクロリド (BTEAC)

*本報を「相問移韧出媒を用いるボリエーテルの合成 第 3 報」とする.

*1 東京工業大学工学部有機材料工学科（１52 東京都 目黒区大岡山 2-12-1)
は，市肘品をそのまま使用した，スチレン及びクロルメ チルスチレンは，常法により精製して用い,トリフルキ ルフミン ( $\left.\mathrm{R}_{3} \mathrm{~N}: \mathrm{R}=\mathrm{CH}_{3} \sim \mathrm{C}_{8} \mathrm{H}_{17}\right)$ は市販品をそのまま 使用した.

2.2 スチレンーヒニルヘンジルトリアルキルアンモニ ウムクロリト共些合体の合成

スチレンとクロルメチルスチレンの仕込み比を種々に 変化させ, ヘンゼン溶液中, 過酸化ベンソイルを開始剤

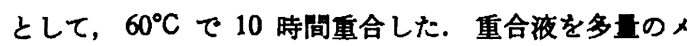
タノール中に投入し，沈殿したボリマーをロ別，祀燥し スチレンークロロメチルスチレン共重合体を得た。この 共重合体をクロロメチル基に対して 50 倍田の $\mathrm{R}_{\mathrm{g}} \mathrm{N}$ と エタノール中で反応させた. 共重合体は, 始めエタノー ルに不溶であるか，四級化が進さとェタノールに可溶と なり均一溶液になった。したがって，四級化反応は，エ タノール中で $\mathrm{R}_{8} \mathrm{~N}$ の存在下で加熱摆流し, 均一溶液に なってから更に 3 日間加熱罢流を続けた. 反応液からエ タノールを留去し, 石油エーテルで良く洗浄した後, 再 びェタノールに室温で溶解し，石油エーテルを用いて再 沈殿精製を行った.このよらにして得られた共重合体の 略号, 性質を Table 1 に示す. なお，表中の $\mathrm{Q}^{+} \mathrm{Cl}^{-}$ の含量は，スチレンークロロメチルスチレン共重合体の 塩素含业から，100\% 四級化が進んだすのとして計算し た値であり，粘度平均分子量 $M_{v}$ は， $[\eta]=3.7 \times 10^{-4}$ $M_{v}^{0.02}\left(\text { トルエン中, } 30^{\circ} \mathrm{C}\right)^{0)}$ を，スチレンークロロメチ ルスチレン共重合体に対して简便的に適用し， $M_{v}$ を求 め分子量の目安とした。粘度は, 共重合体組成によって 変化すると考えられるので，分子量と触媒奻果について は，正確な绩報は示していない。 
Table 1. Abbreviation of copolymer catalysts

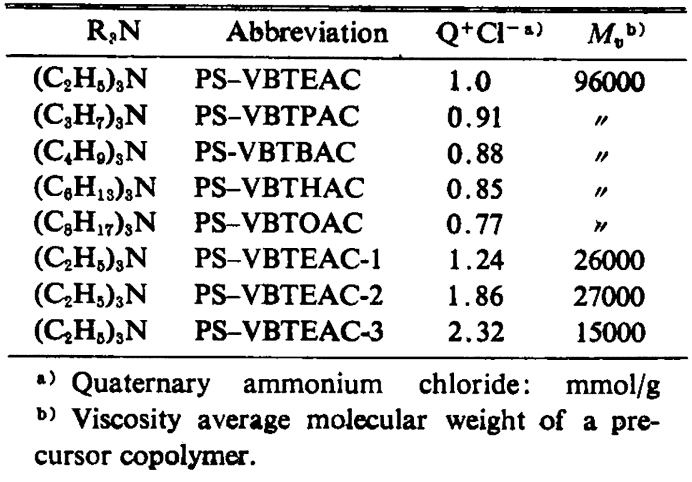

\section{3 臬合方法}

DCPX $(5.0 \mathrm{mmol})$, BPA $(5.0 \mathrm{mmol})$, 共重合体触 媒 $(0.5 \mathrm{~g})$ を $50 \mathrm{ml}$ のフラスコ中にとり, THF-DMSO (3:1) の混合夜 $20 \mathrm{ml}$ に溶解し， $60^{\circ} \mathrm{C}$ に加熱する. 次 いで 50\% 水酸化ナトリウム水溶液 $20 \mathrm{ml}$ を添加し, $60^{\circ} \mathrm{C}$ で湤しくかきまぜながら所定時間重合する、生成 するポリエーテルは，対数粘度が約 $0.2 \mathrm{~g} \cdot \mathrm{d} l^{-1}$ (NMP 中， $\left.30^{\circ} \mathrm{C}\right)$ になると沈殿するので，反応系はしたいた 不均一系になる、反応液を多量の氷水中に投入し，希塩 酸で中和後，重合体を口胡し室温で減圧䡎嬠する，触媒 として使用した共重合体は，ェタノールに可溶なので, エタノールで約 15 時間ソックスレー抽出を行い, ェタ ノール可溶のオリゴマーす同時に除去し，ボリエーテル を得た.このポリエーテルの IR スベクトル及び虽点

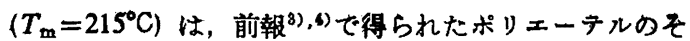
れらと良く一致した。

\section{4 亘合系の相分雒}

THF-DMSO (3:1) 混合溶媒とアルカリ水溶液を同体 䅡，目盛付き試耠管にとり，よく振り混ぜる、次いで 10 分間搫贯し, 界面の位艋を読み取り， level を次の小 ら火計算した。

$L=$ level of interface (\%)

$=\frac{\mathbf{A} \text { 一振り混ぜた後の界面の位置 }}{\text { 振り混ぜる首面の位圈 }(\mathbf{A})} \times 100$

上式で， $L=0$ は 2 相は完全に分離していることを示し， $L=100$ は自由混合を示している．また負のA値は水か 有機相中に移动していることを示し，正のA值は有機溶 某が水相中に移動していることを示している.

\section{3 結果及ひ考暴}

DCPX とBPA との相関移諲重樎合反応においてポ リスチレン (PS: 粘度平㚬分子量 35,000) を添加した ときの結果を，Fig. 1 に示した。困より明らかなよう にPS が存在する重合系では, 重合速度 (生成ポリエー テルの粘度上䒜速度) が速くなっている．これは，PS

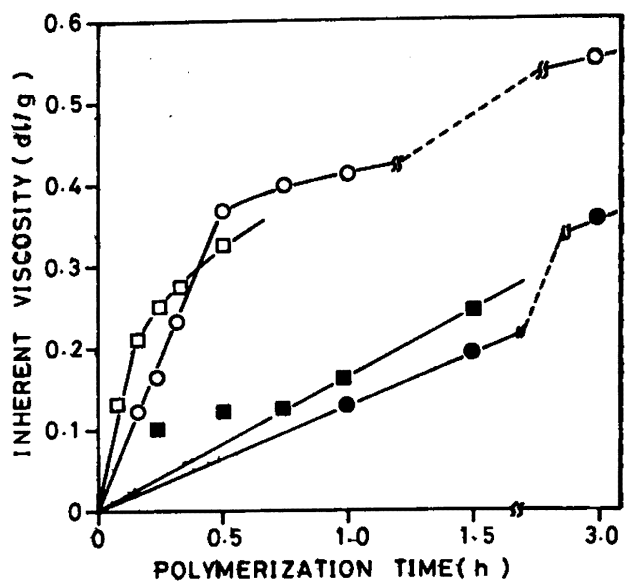

Fig. 1. Polycondensation of DCPX with BPA in the presence of polystyrene (PS) and/or BTEAC in a THF-DMSO $(3: 1) / 50 \% \mathrm{NaOH}$ system at $60^{\circ} \mathrm{C}$ without PS and BTEAC (O), with BTEAC (O), with PS ( $\square$ ), and with PS and BTEAC ( $\square$ ).

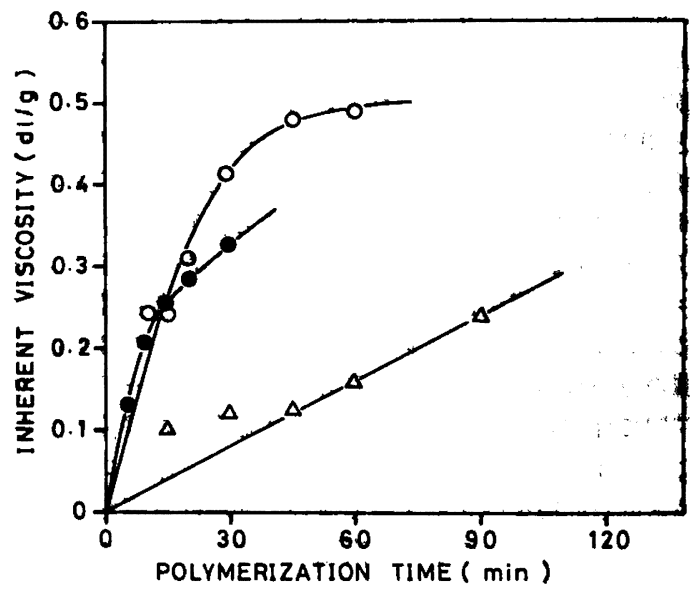

Fig. 2. Catalytic effect of PS-VBTEAC on polycondensation of DCPX with BPA in the presence of PS $(\triangle)$, PS and BTEAC (O), or PS-VBTEAC (O) in a THF-DMSO $(3: 1) / 50 \% \mathrm{NaOH}$ system at $60^{\circ} \mathrm{C}$.

の溶解に伴って有機浴媒の一部が PS に吸着され， DCPX と BPA の実効算度が增加したのが主たる原因 と考えた. Fig. 1 では, PS と BTEACがそれだれ単 独に存在している场合の実験結果を示したが，炏にこれ らを共重合体に組み込んだ场合について検討を行った。

高分子触媒 PS-VBTEAC-1 を重合系中に存在させた ときの重合結果を，Fig. 2 に示した，其重合体とした 時の方が，PS と BTEAC とがそれぞれ単䖵に存在して 
ボリエーテル生成反态におけるスチレンーピニルベンシルトリアルキルフンモニウムクロリド共重合体の触媒效果

Table 2. Polycondensation of DCPX with BPA in a THF-DMSO(3: 1$) / 50 \%$ aqueous $\mathrm{NaOH}$ solution system at $60^{\circ} \mathrm{C}$ with a copolymer catalyst

\begin{tabular}{|c|c|c|c|c|c|c|c|c|}
\hline \multirow{2}{*}{$\begin{array}{l}\text { DCPX } \\
\text { (mmol) }\end{array}$} & \multirow{2}{*}{$\begin{array}{c}\text { BPA } \\
(\mathrm{mmol})\end{array}$} & \multicolumn{4}{|c|}{ Catalyst } & \multirow{2}{*}{$\begin{array}{c}\text { Polymerization } \\
\text { Time }\end{array}$} & \multicolumn{2}{|c|}{ Polymer } \\
\hline & & Polymer & (g) & $\mathrm{Q}^{+} \mathrm{Cl}^{-}$ & $(\mathrm{mmol})$ & & Yield & $\eta_{\operatorname{lnh}}$ \\
\hline 5.0 & 5.0 & & - & & - & $3 \mathrm{~h}$ & $88 \%$ & $0.35 \mathrm{~d} l / \mathrm{g}$ \\
\hline 5.0 & 5.0 & PS & 0.5 & BTEAC & 1.0 & $3 \mathrm{~h}$ & 95 & 0.54 \\
\hline 5.0 & 5.0 & PS & - & & 一 & $2 \mathrm{~h}$ & 86 & 0.25 \\
\hline 5.0 & 5.0 & PS & 0.5 & BTEAC & 1.0 & $45 \mathrm{~min}$ & 90 & 0.35 \\
\hline 5.0 & 5.0 & PS-VBTEAC-1 & 0.5 & VBTEAC & 0.6 & $45 \mathrm{~min}$ & 98 & 0.47 \\
\hline 5.0 & 5.0 & PS-VBTEAC-2 & 0.5 & VBTEAC & 0.9 & $45 \mathrm{~min}$ & 97 & 0.47 \\
\hline 5.0 & 5.0 & PS-VBTEAC-3 & 0.5 & VBTEAC & 1.2 & $45 \mathrm{~min}$ & 98 & 0.48 \\
\hline
\end{tabular}

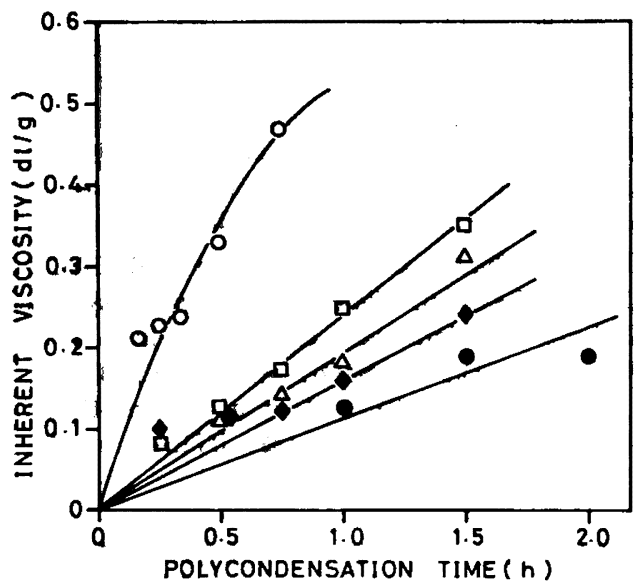

Fig. 3. Polycondensation of DCPX with BPA in a THF-DMSO (3: 1$) / 50 \% \mathrm{NaOH}$ system at $60^{\circ} \mathrm{C}$ with PS-VBTEAC-2 $(0.5 \mathrm{~g},(0), 0.1 \mathrm{~g},(\square), 0.05 \mathrm{~g}$, $(\triangle))$, PS $(0.5 \mathrm{~g},(\bullet))$, and without PS and PSVBTEAC-2 (O).

いる場合より優れており，短時間で高粘度のポリメーテ ルが得られる (Fig. 1 と Fig. 2)，四级坆濩度で比較す ると, 共重合体では $0.62 \mathrm{mmol}$, PS+BTEAC では $1.0 \mathrm{mmol}$ と約半分で良い. しか子高分子量のポリェー テルがは任定量的に得られることからす，共重合体触媒 の四級塩近傍は，高分子量のポリエーテルを生成するの に好都合な䆥囲気になっていると考えられる. Table 2 に，重合結果を示した．触媒が存在しないと 3 時間の重 合て収率 $88 \%$ ，対数粘度 $0.35 \mathrm{~d} l \cdot \mathrm{g}^{-1}$ であるのに 対し て，BTEAC ては 3 時間て，収率 95\% 対数粘度 0.54 $\mathrm{g} \cdot \mathrm{d} l^{-1}$ であった．また共重合体触媒では，45 分で対数 粘度が的 $0.5 \mathrm{~d} l \cdot \mathrm{g}^{-1}$ のポリエーテルがは注量的に得 られた. しかし PS-VBTEAC-1 ないし PS-VBTEAC-3 (共重合体の分子量户四耙塩の分子鎖内での分布及び 含 吾に多少差異がある）を用いた場合，触媒能に著しい善

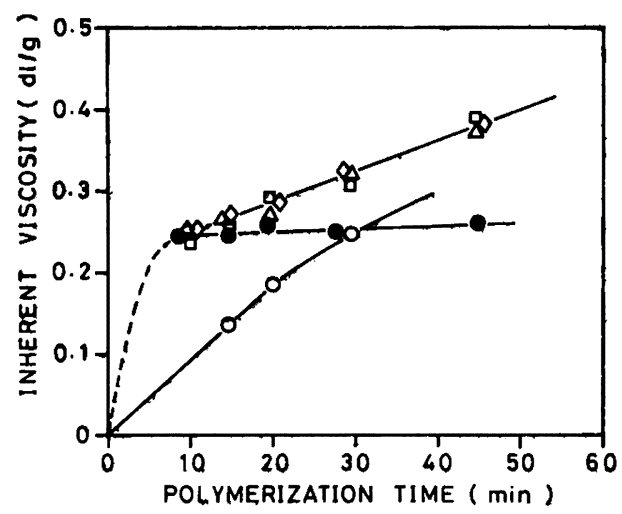

Fig. 4. Catalytic effect of copolymers of styrene and vinylbenzyltrialkylammonium chloride.

Polycondenzations were carried out with $0.5 \mathrm{~g}$ of a copolymer in a THF-DMSO $(3: 1) / 50 \% \mathrm{NaOH}$ system at $60^{\circ} \mathrm{C}$ : PS-VBTEAC (O), PS-VBTPAC $(\diamond)$, PS-VBTBAC ( $\square)$, PS-VBTHAC $(\Delta)$, and PS-VBTOAC (O).

は認められなかった。

Fig. 3 に，触媒量を変化させた時の生成ボリマーの 粘度变化を示した. 共重合体 PS-VBTEAC-1 がごくわ ずか重合系中に存在すると, PS が $0.5 \mathrm{~g}$ 重合系中に存 在する場合に比较して, 粘度の上异速度が大きくなって おり，PS の场合は単にマトリックスによる港縮奻果た けと考えられるのに対して，共重合体触媒の場合には， 第四ナンモニウム㙁の触媒她果が発現していると考えら れる.

各種共重合体 (Table 1) を触媒として，重合した场合 の結果を Fig. 4 に示した. PS-VBTEAC では, 重合 時間に伴って粘度はしたいに增大しているか，PSVBTPAC, PS-VBTBAC, PS-VBTHAC で, 重合初 期 (10 分以内) て対数粘度が， $0.25 \mathrm{~d} l \cdot \mathrm{g}^{-1}$ となり，以 後は反応時間ととすにしたいに粘度が增大し， 3 時間で 


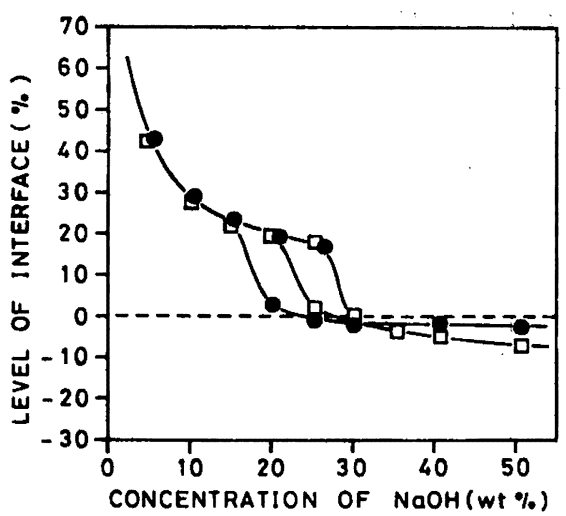

Fig. 5. Changes of interfacial level between organic phase and aqueous sodium hydroxide phase: with PS ( $\square$ ) and without PS (O).

$0.56 \mathrm{~d} l \cdot \mathrm{g}^{-1}$ になった。 しかし PS-VBTOAC の场合に は，重合初期で粘度が， $0.25 \mathrm{~d} l \cdot \mathrm{g}^{-1}$ に迲した後は，反 応時間を長くしても，あまり生成ボリマーの粘度は上㫒 しなかった．以上のことから触媒としてアルキル基の岸 秦数は 2 6 個が透当であると考えられる.これは，第 四フンモニウムクロリドの窒素原子のまわりの実効イオ ン半径（かさ高さ）が触媒能発現に影遙していると考え た. イオン抽出能は，実奻イオン半径とアニオンとの親 和性によって決まり，反応速度は，イオン間距離（実奻 イオン半径の和）によって大きく変化すると考えられる からである.

重合系の相分離の様子を Fig. 5 に示した. THFDMSO (3:1)/ 水酸化ナトリウム水溶液系に PS が存在 する场合と存在しない場合とでは，相分離の様子が多少 異なり，中間相が生成する範囲は，PS が存在すると㹨

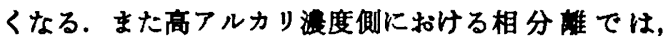
PS が存在すると水が有機相中に約 8\% 注ど溶け込んだ 点で平畺になる．これは，PS を溶解するために THF と DMSO, 特に THF が PS のまわりに吸着され，有 機相中の THF:DMSO の実際の比率は，仕込割合とは 異なっていると考えられる. THF は 50\% 水酸化ナト リウムとは注活完全に相分離するが，DMSO は50\% 水酸化ナトリウムと任意の割合で溶解し合らからであ る. なお共重合体蜰媒については，実際に相分崔の様子 を測定していないか，PS の場合に湆ずるるのと考えら れる.

共重合体触媒と BTEAC の触媒能の差をみるために， PS-VBTEA-2 と BTEAC を用いて，THF-DMSO (3: 1) 及びペンゼン-DMSO (3:1) を有機相として重合した 結果を Fig. 6 に示す.いずれの場合においてす BTEACを触媒として用いると，生成ボリェーテルの対 数粘度はたかたか $0.4 \mathrm{~d} l \cdot g^{-1}$ であったが, PS-VBTEA-

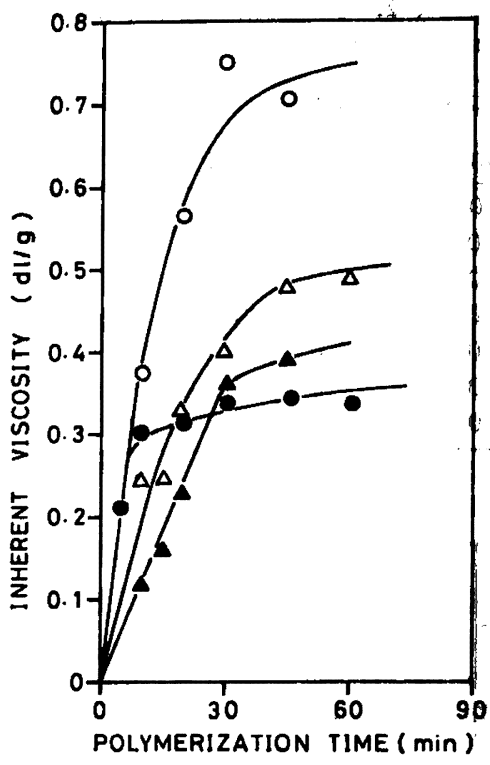

Fig. 6. Changes of catalytic effect of BTEAC or PS-VBTEAC-2 in different polymerization systems. Polycondensations were carried out in a THFDMSO (3: 1)/50\% NaOH system ( $\triangle$ : BTEAC, $\triangle:$ PS-VBTEAC-2), and in a benzene-DMSO (3: 1$) / 50 \% \mathrm{NaOH}$ sytem (O: BTEAC, O PSVBTEAC-2) at $60^{\circ} \mathrm{C}$.

2 が存在すると, THF-DMSO の垐合には対数粘度 0.5 $\mathrm{d} l \cdot \mathrm{g}^{-1}$, ベンゼン-DMSO では対数粘度 $0.74 \mathrm{~d} l \cdot \mathrm{g}^{-1} \mathrm{R}$ まで短時間で到達した．また BTEAC の場合ですべン せン-DMSO 中での重合の方が THF-DMSO 中での重 合の場合上り，初期重合速度（生成ボリマーの粘度上畀 速度）が著しく大きいことから，四級醏を用いての重合 では，ベンゼンのような非橝性溶媒中の方が活性が高い が，生成ポリマーの粘度を高めるには，THF-DMSO のよらな組合せが良い，しかし，高分子触媒を用いると 低分子䖵媒の场合と異なり，ベンゼン-DMSO 中での重 合の方か，短時間で高分子量のボリェーテルが得 られ る.これはおそらく，共重合体の㧹合には，四級塩の近 倿はスチレン単位によって取り囲まれており，媡水掅中 での裸のイオンのよらな票囲気をつくって触媒活性が著 しく高められ，Fig. 6 のよ5な結果になったと考えら れる. しかし高分子ミセル効果があるかどらか恃不明で あるが，共重合体とすることによって，䖵媒活性の场を 作り出すことができ，その効果は BTEAC がペンぜンー DMSO 中で浮遊している㙛合に比へてて，著しく大きい ことがわかった。 また共重合体触媒の作用機鹤は， Starks) の提唱した，いわゆる相間移䖝の機椿とは多少 县なるよらК思われる。 
ポリエーテル生成反応に拈けるスチレンービニルベンジルリアルキルアンモニウムクロリド共重合体の触媒効果

付＼cjkstart本研究は，第 33 回高分子年次大会（1984 年

5 月，名古座）において報告した。

\section{女妾}

1) T. D. Guyen and S. Boileau, Polym. Bull. 1, 817 (1979).

2) G. G. Cameron and K. S. Law, Makromol.
Chem., Rapid. Commun., 3, 99 (1982).

3) N. Yamazaki and Y. Imai, Polym. J., 15, 603 (1983).

4) N. Yamazaki and Y. Imai, Polym. J., 投稿中.

5) C. M. Starks, J. Am. Chem. Soc., 93, 195 (1971).

6) Goldberg, Hohenstein, and Mark, J. Polym. Sci., 2, 502 (1947)

Catalytic Effect of Styrene-Vinylbenzyltrialkylammonium Chloride-Copolymer on Preparation of Polyether from $a, \alpha^{\prime}$-Dichloro-p-xylene and 2,2-Bis(4-hydroxyphenyl)propane*

Yoshio IMAI*1 and Noboru YAMAZAKI*1

"Studies on the Phase Transfer Catalyzed Polycondensation. III.

-1Department of Textile and Polymeric Materials, Faculty of Engineering, Tokyo Institute of Technology (12-1, Ookayama, 2-chome, Meguro-ku, Tokyo, 152 Japan)

Copolymers of styrene and various vinylbenzyltrialkylammonium chloride (CPC) were prepared by the treatment of a copolymer of styrene and chloromethylstyrene with corresponding trialkylamines. Polycondensations of $\alpha, \alpha^{\prime}$-dichloro-p-xylene with 2,2-bis(4-hydroxyphenyl)propane(BPA) were carried out in THF-or benzeneDMSO $/ 50 \%$ aqueous $\mathrm{NaOH}$ solution system with $\mathrm{CPC}$ at $60^{\circ} \mathrm{C}$. When a styrene-vinylbenzyltriethylammonium chloride copolymer(I) was used as a catalyst, inherent viscosity of the resulting polymer reached to $0.74 \mathrm{dl} \mathrm{g}^{-1}$ in benzene-DMSO(3: 1)/50\% aqueous solution for $30 \mathrm{~min}$. Catalytic effect of I was also compared with polystyrene and benzyltriethylammonium chloride.

KEY WORDS Phase Transfer Catalyzed Reaction / Polymeric Quaternary Ammonium Chloride / Polycondensation / $\alpha, \alpha^{\prime}$-Dichloro-p-xylene / 2,2-Bis(4-hydroxyphenyl)propane / Polyether /

(Received July 9, 1984: Accepted August 31, 1984)

[Kobunshi Ronbunshu, 42 (1), 49-53 (1985)] 